LAPORAN KASUS

\title{
Early Percutaneous Dilatational Tracheostomy pada Pasien COVID-19 dengan Gagal Napas: Laporan Kasus
}

\section{Early Percutaneous Dilatational Tracheostomy in Respiratory Failure Covid-19 Patient: A Case Report}

Ahmad Feza Fadhlurrahman ${ }^{\bowtie}$, Rudy Vitraludyono, Taufiq Agus Siswagama, Arie Zainul Fatoni

Departemen Anestesiologi dan Terapi Intensif, Fakultas Kedokteran, Universitas Brawijaya/RSUD Dr. Saiful Anwar, Malang, Indonesia

${ }^{\square}$ Korespondensi: fezafadhlurrahman@ub.ac.id

\begin{abstract}
Background: Critical patients with coronavirus disease 2019 (COVID-19) infection have a predisposition to prolonged mechanical ventilation treatment. Treatment with long-term translaryngeal intubation along with sedation and other measures in the intensive care unit (ICU) can lead to some further complications.

Case: Post-caesarean section female patient with respiratory failure due to COVID-19 infection. This patient received high flow nasal canule (HFNC) support early in her ICU stay. 4 days of treatment, the patient's respiratory distress was severe and translaryngeal intubation was performed. From evaluating the patient's condition for 4 days of treatment with mechanical ventilation, the ICU team decided to perform a tracheostomy through a percutaneous dilatation approach. The procedure was carried out in a negative pressure room with the use of level 3 personal protective equipment (PPE). The patient's condition gradually improved during 7 days of treatment with tracheostomy. Minimal ventilatory support, decreased oxygen fraction requirements and improvement in general conditions are some considerations to decanulation procedure. 3 days after decanulation, the patient was transferred to a room with a stable condition.
\end{abstract}

During treatment in the ICU, patient received standard therapy in the form of antivirals, antibiotics, anticoagulants, analgesics, steroids, and other supporting drugs.

Discussion: Tracheostomy was associated with a lower incidence of pneumonia, decreased use of sedation agents and an accelerated period of discharge from mechanical ventilation. Early tracheostomy was performed before the 10th day of intubation. The percutaneous dilation technique offers cost effectiveness and efficiency of supporting tools. Percutaneous dilatational tracheostomy (PDT) in COVID-19 patients must be carried out with optimal protection for medical personnel.

Conclusion: Early tracheostomy can be considered in the management of critically ill COVID-19 patients. Assessment of patient's clinical condition and protection of medical personnel are the main factors in determining early tracheotomy in COVID-19 patients.

Keywords: ARDS; COVID-19 infection; percutaneous dilatational; respiratory failure; tracheostomy 


\begin{abstract}
ABSTRAK
Latar belakang: Pasien kritis dengan infeksi coronavirus disease 2019 (COVID-19) memiliki kecenderungan untuk perawatan ventilasi mekanik dalam waktu yang lama. Perawatan dengan translaryngeal intubasi dalam waktu lama beserta penggunaan sedasi dan tindakan lainnya di intensive care unit (ICU) dapat memunculkan beberapa komplikasi lebih lanjut.

Kasus: Pasien perempuan pascaoperasi sectio caesaria dengan gagal napas akibat infeksi COVID-19. Pasien mendapat support high flow nasal canule (HFNC) di awal perawatan di ICU. 4 hari perawatan, kondisi distress napas pasien memberat dan dilakukan intubasi translaryngeal. Dari evaluasi kondisi pasien selama 4 hari perawatan dengan ventilasi mekanik, tim ICU memutuskan melakukan tracheostomy melalui pendekatan dilatasi perkutan. Prosedur dilakukan di ruang bertekanan negatif dengan penggunaan alat pelindung diri (APD) level 3. Kondisi pasien berangsur mengalami perbaikan selama 7 hari perawatan dengan tracheostomy. Support ventilasi yang minimal, kebutuhan fraksi oksigen yg menurun dan perbaikan kondisi umum menjadi pertimbangan dilakukan dekanulasi. 3 hari pasca dekanulasi pasien dipindah rawat ke ruangan dengan kondisi stabil.

Selama perawatan di ICU, pasien mendapat standar terapi berupa antiviral, antibiotik, antikoagulan, analgesik, steroid, dan obat penunjang lainnya.

Pembahasan: Tindakan tracheostomy berhubungan dengan insiden pneumonia yang lebih rendah, penurunan penggunaan obat sedasi dan percepatan masa lepas rawat dari ventilasi mekanik. Early tracheostomy dilakukan sebelum hari ke-10 intubasi. Teknik dilatasi perkutan memiliki kelebihan atas efektifitas dan efisiensi biaya dan alat pendukung. Tindakan percutaneous dilatational tracheostomy (PDT) pada pasien COVID-19 harus dilakukan dengan proteksi tenaga medis yang optimal.

Kesimpulan: Early tracheostomy dapat dipertimbangkan dalam tatalaksana pasien kritis COVID-19. Penilaian kondisi klinis pasien dan proteksi tenaga medis merupakan faktor utama menentukan tindakan early tracheostomy pada pasien COVID-19.
\end{abstract}

Kata Kunci: ARDS; COVID-19; dilatasi perkutan; gagal napas; tracheostomy 


\section{PENDAHULUAN}

Infeksi virus severe acute respiratory syndrome coronavirus 2 (SARS CoV-2) yang merupakan penyebab kondisi coronavirus disease 19 (COVID-19) telah menjadi permasalahan global dengan status pandemi. ${ }^{1}$ Di Indonesia, sejak pertama kali di umumkan pada tanggal 2 Maret 2020, penambahan jumlah kasus konfirmasi meningkat dari waktu kewaktu. Pada 31 Desember 2020 terdapat 743.196 kasus dengan tingkat mortalitas sebanyak 22.138 kasus dan tingkat sembuh sebanyak $611.097 .^{2}$

Manifestasi klinis dari COVID-19 berupa gejala ringan $(80,9 \%)$, sedangberat $(13,8 \%)$ dan kritis $(4,7 \%)$. Pasien dengan kondisi kritis memiliki angka mortalitas tinggi yang disebabkan karena disfungsi organ berupa Acute respiratory distress syndrome (ARDS) (67\%), acute kidney injury (29\%), cardiac injury (23\%) dan disfungsi hati (29\%). Disfungsi organ yang terjadi mengharuskan pasien dalam kategori kritis mendapatkan perawatan di ruang intensive dimana Sebagian besar pasien yang dirawat di ICU (80\%) akan membutuhkan ventilasi mekanik baik jangka pendek maupun panjang. ${ }^{3}$ Tracheostomy merupakan tindakan yang sering dilakukan pada pasien kritis dengan penggunaan ventilasi mekanik dalam jangka panjang dan memiliki tingkat prevalensi sekitar $13 \%$ pada pasien dengan ARDS. ${ }^{4}$

Munculnya COVID-19 yang merupakan penyakit baru dengan tingkat penyebaran yang cepat mengakibatkan perkembangan yang cepat pula pada guideline yang ada. Beberapa guideline awal pada kondisi COVID-19 tidak menyarankan tindakan tracheostomy sebelum hari ke 10 intubasi dan diperlukan pertimbangan matang apabila tracheostomy dilakukan pada hari ke 10-2 intubasi sehubungan dengan tingkat load dari virus. ${ }^{5}$ Safety dari tenaga kesehatan juga menjadi pertimbangan dalam tindakan tracheostomy, beberapa pusat layanan kesehatan mensyaratkan hasil swab PCR SARS CoV2 negatif dan membatasi jumlah tindakan harian. ${ }^{6}$ Beberapa guideline terbaru menunjukkan pertimbangan yang lebih moderat. Diperlukan analisis yang baik antara manfaat dan risiko yang ada, waktu ideal sehubungan dengan outcome pasien dan keselamatan dari tenaga medis yang melaksanakan tracheostomy. $^{7}$

Early tracheostomy merupakan tindakan tracheostomy yang dilakukan sebelum hari ke 10 intubasi. ${ }^{4}$ Tracheostomy dapat menurunkan kebutuhan sedasi, menghindari trauma jalan napas karena tekanan, dan menurunkan deconditioning fisik sehubungan dengan ventilasi mekanik yang lama. Walaupun bukti ilmiah tracheostomy dalam meningkatkan tingkat survival masih belum jelas, namun dari beberapa metaanalysis, tracheostomy berhubungan dengan tingkat insiden pneumonia yang lebih rendah. ${ }^{8}$ Penggantian tube translaryngeal dengan tracheostomy menurunkan kejadian lesi pada rongga mulut dan memperbaiki higyenitas mulut. Teknik percutaneous dilatational tracheostomy memiliki beberapa keunggulan diantaranya lebih efektif dalam pembiayaan dan efisiensi tenaga dan kebutuhan pendukung lainnya. ${ }^{4}$

Sebuah studi di Italia mengenai early tracheostomy pada pasien COVID-19 melibatkan 164 pasien terintubasi sampai dengan hari ke-4 perawatan. Dari pasien yang menjalani early tracheostomy (74\%) maupun tidak 
(26\%) didapatkan tingkat hospital mortality yang lebih rendah secara signifikan pada kelompok early tracheostomy $(62,8 \%$ vs $45,5 \%) .{ }^{4}$ Studi lainnya berupa studi restrospective di New York terhadap 148 pasien COVID19 dengan tracheostomy, menunjukkan pasien dengan early tracheostomy (52 pasien) memiliki lama waktu perawatan yang lebih rendah secara rata-rata dibandingkan pasien dengan late tracheostomy (96 pasien). ${ }^{9}$

\section{KASUS}

Riwayat Penyakit

Pasien perempuan dengan G2P1001Ab000 34-36 minggu dirujuk dari rumah sakit perujuk dengan keluhan utama sesak sejak 1 hari sebelum masuk rumah sakit. Sebelumnya pasien mengalami demam selama 10 hari dan batuk 3 hari. Pasien menjalani operasi sectio caesaria dengan indikasi distress pada ibu dan bayi. Operasi berjalan lancar dengan tindakan anestesi berupa spinal anestesi. Pascaoperasi pasien dirawat di ruang ICU.

Pemeriksaan Fisik

Tabel 1. Pemeriksaan penunjang hari pertama

\begin{tabular}{llll}
\hline \multicolumn{1}{c}{ Laboratorium } & \multicolumn{1}{c}{ Nilai } & \multicolumn{1}{c}{ Laboratorium } & Nilai \\
\hline $\mathrm{Hb}(\mathrm{g} / \mathrm{dL})$ & 11,2 & SGOT/SGPT $(\mathrm{U} / \mathrm{L})$ & $38 / 15$ \\
$\mathrm{WBC}\left(10^{3} / \mu \mathrm{L}\right)$ & 9,24 & Albumin $(\mathrm{g} / \mathrm{dL})$ & 2,9 \\
Trombosit $\left(10^{3} / \mu \mathrm{L}\right)$ & 187 & Ur/Cr $(\mathrm{mg} / \mathrm{dL})$ & $12,2 / 0,56$ \\
$\mathrm{NLR}$ & 9,33 & D dimer $(\mathrm{mg} / \mathrm{L})$ & 1,4 \\
$\mathrm{GDS}(\mathrm{mg} / \mathrm{dl})$ & 72 & CRP $(\mathrm{mg} / \mathrm{dL})$ & 16,97 \\
Elektrolit $(\mathrm{Na} / \mathrm{K} / \mathrm{Cl})$ & $137 / 3,67 / 107$ & P/F ratio & 89,5 \\
$(\mathrm{mmol} / \mathrm{L})$ & & & \\
\hline
\end{tabular}

Pasien dirawat di ICU pascaoperasi dengan kondisi klinis RR 30-35x/menit, napas simetris, menggunakan oksigenasi NRBM 15 lpm, didapatkan SpO2 90\%. TD 94/53 dengan nadi 101x/'. GCS 456, produksi urin $350 \mathrm{cc} / 6$ jam.

Pemeriksaan Penunjang

Perawatan ICU

Dari evaluasi awal pasien di ICU, tim memutuskan memberikan high flow nasal canule (HFNC) sebagai support oksigenasi. Setting awal flow $50 \mathrm{lpm}$, FiO2 80\%, SpO2 pasien meningkat menjadi 95-96\%, dengan ROX index 4,08. Tatalaksana pasien secara umum disesuaikan dengan protokol pasien kritis COVID-19 dengan pemberian antibiotik levofloksasin, antiviral favipiravir, antikoagulan, analgesik dan penunjang berupa vitamin $\mathrm{C}$, zinc dan $N$-Acetyl cysteine.
Pada hari ke-4 perawatan dengan HFNC support oksigenasi pasien bertambah menjadi $60 \mathrm{lpm}$ dengan $\mathrm{FiO} 2100 \%$, kondisi klinis saat itu dengan RR 40-42 $\mathrm{x} /$ menit dengan $\mathrm{SpO} 2$ 88-90\%, ROX index berada pada 2,14. Tim perawatan ICU memutuskan mengganti support oksigenasi menjadi noninvasive ventilation (NIV). Setelah penggunaan NIV dalam waktu 1 jam, tidak ada perbaikan signifikan terhadap kondisi klinis pasien dan penilaian skor HACOR menunjukkan nilai 13, sehingga diputuskan untuk dilakukan intubasi endotrakeal dan penggunaan mechanical ventilation. Setting ventilator awal pada pasien ini dengan mode PCV, Pins 20, RR 30, PEEP 10, I:E 1:1,5, FiO2 90\%. Klinis pada pasien RR 30x/menit, Tidal Volume 250-270, ETCO2 53, SpO2 95-96\%. 


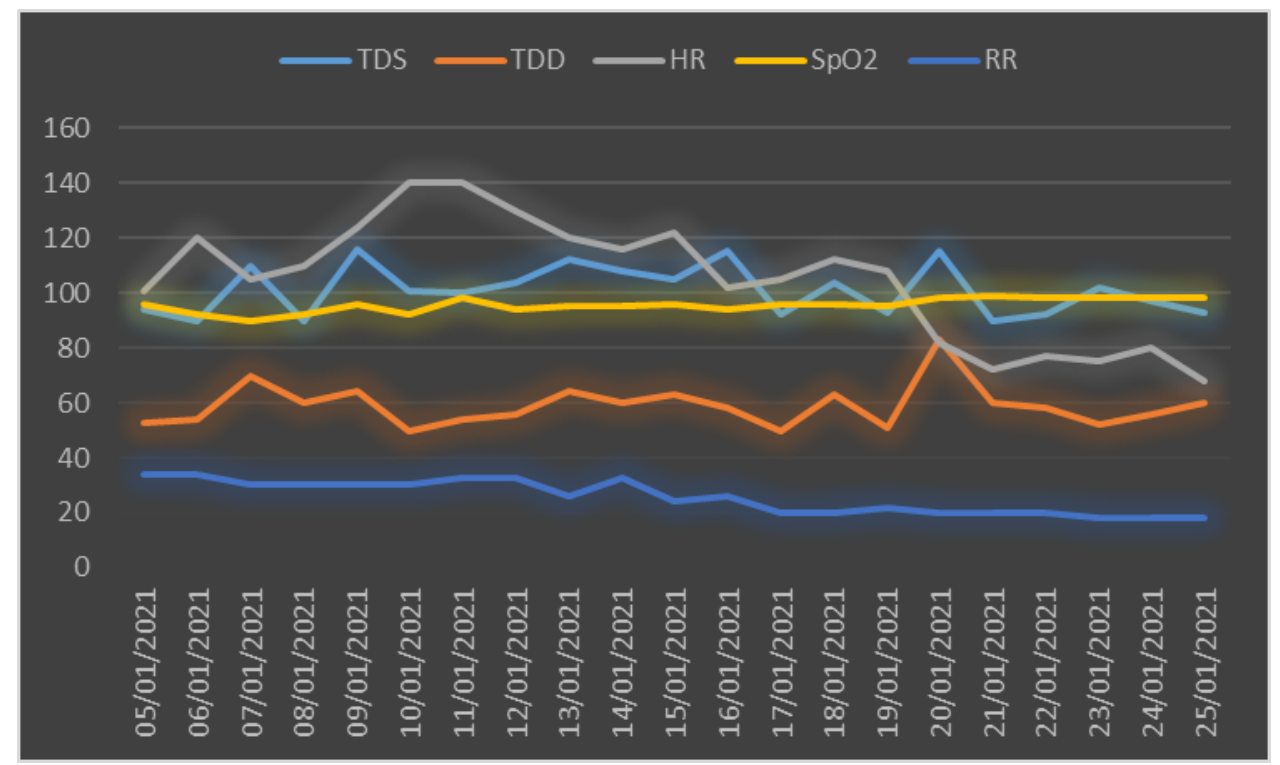

Gambar 1. Grafik tanda vital harian

Hari ke-4 perawatan dengan mechanical ventilation, tim perawatan ICU memutuskan untuk melakukan percutaneous tracheostomy. Tindakan dilakukan di ICU dengan tekanan negatif dan tenaga medis menggunakan
APD level 3. Untuk menekan refleks batuk, pasien diberi pelumpuh otot dan dilakukan napas kendali selama prosedur. Pasca tindakan, pasien diberi obat sedasi untuk menjaga sinkronisasi antara pasien dengan ventilator.



Gambar 2. Persiapan tindakan percutaneous dilatational tracheostomy 
Pasien mendapat perawatan dengan percutaneous tracheostomy selama 7 hari dengan perbaikan kondisi klinis dan penunjang. Penggunaan obat sedasi berangsur turun dan berhenti pada hari ke-4 penggunaan percutaneous tracheostomy. Setelah evaluasi mengenai kondisi pasien, penurunan support oksigenasi, kekuatan mempertahankan jalan napas dan refleks batuk, maka dekanulasi dilakukan pada hari perawatan ke-21. Selanjutnya pasien dievaluasi lebih lanjut dan dipindah ke ruang rawat pada hari ke-25 dalam kondisi stabil.

Tabel 2. Perkembangan kondisi pasien

\begin{tabular}{|c|c|c|c|c|}
\hline Tanggal & $5 / 02$ & $9 / 02$ & $14 / 02$ & 21 \\
\hline Sedasi & $\begin{array}{l}\text { Dexmedetomidin } \\
\text { e syringe } \\
0,3 \mathrm{mcg} / \mathrm{kg} / \mathrm{mnt}\end{array}$ & $\begin{array}{l}\text { Midazolam 3-4 } \\
\mathrm{mg} / \text { jam }\end{array}$ & $\begin{array}{l}\text { Midazolam } \\
2 \mathrm{mg} / \mathrm{jam}\end{array}$ & - \\
\hline $\begin{array}{l}\mathrm{P} / \mathrm{F} \text { ratio } \\
\text { Oksigena } \\
\text { si dan } \\
\text { Ventilasi }\end{array}$ & $\begin{array}{l}89,5 \\
\text { HFNC }\end{array}$ & $\begin{array}{l}95,8 \\
\text { Translaryngeal tube } \\
\text { MV }\end{array}$ & $\begin{array}{l}103 \\
\text { Tracheostomy MV }\end{array}$ & $\begin{array}{l}193 \\
\text { NRBM }\end{array}$ \\
\hline $\begin{array}{l}\text { Foto } \\
\text { Thorak }\end{array}$ & & & & \\
\hline
\end{tabular}

\section{PEMBAHASAN}

Pandemi COVID-19 telah mengakibatkan peningkatan jumlah pasien dengan kriteria kritis dan memerlukan ventilasi mekanik. Pasien gagal napas karena infeksi COVID-19 pada umumnya membutuhkan perawatan dengan ventilasi mekanik selama 2-3 minggu. ${ }^{10}$ Tracheostomy merupakan tindakan yang umum dilakukan pada pasien kritis yang membutuhkan perawatan jangka panjang dengan ventilasi mekanik. Pada beberapa kondisi, tracheostomy dapat mempercepat proses weaning dari ventilator. Kondisi tersebut tentu dinilai bermanfaat pada kondisi pandemi dimana terjadi ketidaksesuaian antara kebutuhan dan ketersediaan dari perawatan ICU dengan ventilasi mekanik. ${ }^{11,12}$

Saat awal pandemi, beberapa guideline menyarankan untuk menghindari atau menunda tracheostomy pada pasien COVID-19. Pertimbangan terhadap sifatnya yang merupakan aerosol generating procedure (AGP) dan safety terhadap tenaga medis mendasari kondisi tersebut. ${ }^{4,13}$ Beberapa rekomendasi lain menyarankan tracheostomy dilakukan pada hari 10-21 setelah intubasi. Periode tersebut dinilai memiliki viral load yang lebih sedikit. ${ }^{1,9}$ Walaupun penundaan tracheostomy meminimalisir risiko terhadap tenaga 
medis, namun pemanjangan perawatan dengan translaryngeal intubasi beserta penggunaan sedasi, ventilasi mekanik dan ICU dapat memunculkan beberapa komplikasi lebih lanjut. ${ }^{12}$

Dari beberapa publikasi terkini pada pasien dengan COVID-19, tindakan early tracheostomy dapat dipertimbangkan secara klinis dan aman untuk dikerjakan dengan ketersediaan alat pelindung diri yang memadai. Namun, manfaat secara langsung early tracheostomy terhadap kondisi pasien COVID-19 masih belum jelas. $^{10}$ Insidensi pneumonia yang lebih rendah, penurunan penggunaan obat sedasi, percepatan masa lepas rawat dari ventilasi mekanik menjadi keunggulan yang ditawarkan early tracheostomy pada kondisi tertentu. ${ }^{1}$

Keputusan tracheostomy pada kasus ini dilakukan pada hari ke-4 pasca intubasi dengan pertimbangan: tindakan ini berada pada hari ke-14 setelah gejala awal, kondisi pasien yang cukup baik dengan support ventilasi yang lebih rendah dari saat awal intubasi dan pencegahan terjadinya komplikasi lebih lanjut. Masa infeksius puncak pada pasien COVID-19 diperkirakan terjadi pada pra atau saat awal timbul gejala dan semakin menurun setelahnya. ${ }^{12,14}$ Sehingga pasien ini dinilai memiliki tingkat infeksi virus yang lebih rendah saat dilakukan tindakan. Support ventilasi dan fraksi oksigen yang lebih rendah menghindarkan kemungkinan pasien untuk dilakukan posisi prone sebagai strategi ventilasi pada pasien COVID-19 dengan ARDS berat. Posisi prone pada pasien dengan tracheostomy berisiko terjadinya displacement alat yang tidak tervisualisasi dan kerusakan akibat tekanan. ${ }^{12}$ Pasien kritis COVID19 dengan ventilasi mekanik memiliki risiko yang lebih besar untuk terjadinya ventilator associated pneumonia (VAP). ${ }^{15}$ Dengan adanya tracheostomy diharapkan dapat memperbaiki higyenitas mulut, yang sering menjadi permasalahan pada kondisi HFNC, NIV maupun translaryngeal tube.

Untuk meminimalisir transmisi virus ke petugas medis, teknik percutaneous tracheostomy dilakukan dengan fasilitasi obat pelumpuh otot guna menghindari pasien batuk saat dilakukan tindakan. Ruangan bertekanan negatif dan penggunaan alat pelindung diri yang optimal (APD level 3) juga menjadi syarat proteksi tenaga medis. ${ }^{13,16}$ Dari tabel 2, dapat kita lihat perkembangan pasien setelah tracheostomy mengalami perbaikan. Walaupun perbaikan kondisi sendiri dapat terjadi secara independen, namun tracheostomy tetap dapat memiliki andil. Peningkatan kenyamanan pasien akibat hilangnya iritan utama di rongga mulut dan tenggorokan mengakibatkan penurunan dosis obat sedasi. ${ }^{4,13}$ Pasien menjadi lebih kooperatif, otonomi dari support mesin ventilasi mekanik didapatkan lebih dini, sehingga pada hari ke-7 tracheostomy pasien dapat dilakukan dekanulasi.

\section{KESIMPULAN}

Early tracheostomy dapat dipertimbangkan dalam tatalaksana pasien kritis COVID-19 dengan ventilasi mekanik yang diprediksi akan memakan waktu yang lama. Pertimbangan tindakan dilakukan berdasar kondisi klinis pasien. Untuk menghindari transmisi virus ke tenaga medis, tindakan harus dilakukan secara aman. Penggunaan APD level 3, ruang isolasi bertekanan negatif dan fasilitasi obat pelumpuh otot selama tindakan dapat membantu mengurangi risiko paparan. 


\section{DAFTAR PUSTAKA}

1. Bangash MN, Breik O, Dawson C, Idle $\mathrm{M}$, Isherwood $\mathrm{P}$, Jennings $\mathrm{C}$, et al., Tracheostomy in COVID-19 safety and 30-day outcomes of the first 100 cases from a single tertiary UK hospital: a prospective observational cohort study, British Journal of Anaesthesia, https://doi.org/10.1016/j.bja.2020.0 8.023 .

2. Burhan E, Susanto AD, Nasution SA, Ginanjar E, Pitoyo CW, Susilo A, et al. Pedoman Tatalaksanan Covid-19. Edisi 3. 2020

3. Shang $\mathrm{Y}$, Pan $\mathrm{C}$, Yang $\mathrm{X}$, Zhong $\mathrm{M}$, Shang $\mathrm{X}, \mathrm{Wu} \mathrm{Z}$, et al. Management of critically ill patients with COVID-19 in ICU: statement from front-line intensive care experts in Wuhan, China. Ann Intensive Care. 2020;10(1):1-24. doi:10.1186/s13613-020-00689-1

4. Rosano, Antonio MD, Martinelli, Enrico C, Fusina, Federica, et al. Early Percutaneous Dilatational Tracheostomy in Coronavirus Disease 2019: Association With Hospital Mortality and Factors Associated With Removal of Tracheostomy Tube at ICU Discharge. A Cohort Study on 121 Patients*, Critical Care Medicine: February 2021 - Volume 49 - Issue 2 - p 261-270 doi: 10.1097/CCM.0000000000004752

5. Takhar A, Walker A, Tricklebank S, Wyncoll D, Hart N, Jacob T, et al. Recommendation of a practical guideline for safe tracheostomy during the COVID-19 pandemic. Eur Arch Oto-Rhino-Laryngology Advance access published on April 13, 2020, doi:10.1007/s00405-02005993-x.

6. Michetti CP, Burlew CC, Bulger EM, Davis KA, Spain DA. Performing tracheostomy during the
Covid-19 pandemic: guidance and recommendations from the Critical Care and Acute Care Surgery Committees of the American Association for the Surgery of Trauma. Trauma Surg Acute Care Open 2020; 5: e000482

7. McGrath BA, Brenner MJ, Warrillow SJ, Pandian V, Arora A, Cameron TS, et al. Tracheostomy in the COVID-19 era: global and multidisciplinary guidance. Lancet Respir Med Advance access published on May 15, 2020, doi:10.1016/S2213-2600(20)302307.

8. Siempos II, Ntaidou TK, Filippidis FT, Choi AMK. Effect of early versus late or no mechanical ventilation: a systematic review and meta-analysis. Lancet Respir Med 2015; 3: 150-8

9. Kwak PE, Connors JR, Benedict PA, Timen MR, Wang B, Zhang Y, Youlios S, et al. Early Outcomes from Early Tracheostomy for Patients With COVID-19. JAMA Otolaryngol Head Neck Surg. 2020 Dec 17:e204837. doi: 10.1001/jamaoto.2020.4837. Epub ahead of print. PMID: 33331855; PMCID: PMC7747038.

10. Carmichael H, Wright FL, McIntyr e RC, Vogler T, Urban S, Jolley $\mathrm{SE}$, et al. Early ventilator liberation and decreased sedation needs after tracheostomy in patients with COVID-19 infection Trauma Surgery \& Acute Care Open 2021;6:e000591. doi: 10.113 6/tsaco-2020-000591

11. Michetti CP, Burlew CC, Bulger EM, Davis KA, Spain DA; Critical Care and Acute Care Surgery Committees of the American Association for the Surgery of Trauma. Performing tracheostomy during the Covid-19 pandemic: 
guidance and recommendations from the Critical Care and Acute Care Surgery Committees of the American Association for the Surgery of Trauma. Trauma Surg Acute Care Open. 2020 Apr 15;5(1):e000482. doi: 10.1136/tsaco-2020-000482.

PMID: $\quad 32368620$; PMCID: PMC7186881.

12. McGrath BA, Brenner MJ, Warrillow SJ, Pandian V, Arora A, Cameron TS, et al. Tracheostomy in the COVID-19 era: global and multidisciplinary guidance. Lancet Respir Med. 2020 Jul;8(7):717-725. doi: $10.1016 /$ S22132600(20)30230-7. Epub 2020 May 15. PMID: 32422180; PMCID: PMC7228735.

13. Sun BJ, Wolff CJ, Bechtold HM, Free D, Lorenzo J, Minot PR, et al. Modified percutaneous tracheostomy in patients with COVID-19. Trauma Surg Acute Care Open. 2020 Dec 14;5(1):e000625. doi: 10.1136/tsaco-2020-000625. PMCID: PMC7736959.
14. Wolfel R, Corman VM, Guggemos W, Seilmaier M, Zange S, Muller MA, et al. Virological assessment of hospitalized patients with COVID-2019. Nature 2020; published online April 1. DOI:10.1038/s41586-020-2196 x.

15. Maes M, Higginson E, Pereira-Dias J, Curran MD, Parmar S, Kokhar F, et al. Ventilator-associated pneumonia in critically ill patients with COVID-19. Crit Care 25, 25 (2021).

https://doi.org/10.1186/s13054-02103460-5

16. Chao TN, Braslow BM, Martin ND, Chalian AA, Atkins J, Haas AR, Rassekh CH; Guidelines from the COVID-19 Tracheotomy Task Force, a Working Group of the Airway Safety Committee of the University of Pennsylvania Health System. Tracheotomy in Ventilated Patients With COVID-19. Ann Surg. 2020 Jul;272(1):e30-e32. doi: 10.1097/SLA.0000000000003956. PMID: 32379079 ; PMCID: PMC7224612. 